Article

\title{
Embedding Higher Education into a Real-World Lab: A Process-Oriented Analysis of Six Transdisciplinary Project Courses
}

\author{
Richard Beecroft ${ }^{1,2}$ (D) \\ 1 Institute for Technology Assessment and Systems Analysis, Karlsruhe Institute of Technology, \\ 76021 Karlsruhe, Germany; richard.beecroft@kit.edu \\ 2 Institute for Ethics and Transdisciplinary Sustainability Research, Leuphana University, \\ 21335 Lüneburg, Germany
}

Received: 12 September 2018; Accepted: 16 October 2018; Published: 20 October 2018

check for updates

\begin{abstract}
Since the early days of the emerging research format of Real-world Labs (RwLs), higher education plays a vital role in them. Examples have been presented on teaching activities in RwLs, but the reasons for and evidence of their inclusion stays limited. To start a systematic discussion on the embedding of higher education in RwLs, this paper presents the case of six Transdisciplinary Project Courses carried out in the RwL "District Future-Urban Lab" in Karlsruhe/Germany. The paper presents the discourses on the role of learning in RwLs and compares it to those on Transition Labs and Urban Living Labs. To offer a new approach to address this aspect, the paper introduces a social practice perspective to map out the interrelations between an $\mathrm{RwL}$ and higher education therein. The detailed analysis of the processes is used to identify the potential of the RwL to support learning. It shows that all dimensions of social practice can be identified in the interplay between Real-world Lab and Transdisciplinary Project Courses, even though to a very different degree and in different phases. The text closes with lessons learned for teaching project courses in RwLs and similar labs.
\end{abstract}

Keywords: higher education for sustainable development; real-world labs; transition labs; living labs; transformative learning; social learning; transdisciplinarity; learning environment; social practice

\section{Introduction}

Real-world Laboratories (RwLs) are part of a quickly evolving field of transformative science. Along numerous other types of "labs", such as Transition Labs, Transformation Labs, and Urban Living Labs, they represent a new style of transdisciplinary and transformative research. Instead of a pure project-based or case study approach, they offer a longer-term supportive structure-the lab - to facilitate transformation beyond a singular intervention, usually oriented towards sustainable development and related goals. This article will exemplify how higher education can make use of this type of support structure, and in turn contribute to it as well. It is based on the experience drawn from six Transdisciplinary Project Courses, which took place between 2014 and 2017 in the RwL "District Future-Urban Lab" in Karlsruhe.

This introduction presents the concept of RwLs and maps out notions of learning in RwLs and two related concepts, Urban Transition Labs and Urban Living Labs, leading to two research questions. The second paragraph introduces the combined qualitative and semi-quantitative methodology of this study, based a social practice perspective and the phase structure of the Transdisciplinary Project Courses. The third paragraph presents a qualitative analysis of the RwL "District Future-Urban $\mathrm{Lab}^{\prime \prime}$ and the fourth a qualitative and semi-quantitative analysis of the Transdisciplinary Project 
Courses therein. The fifth paragraph derives practical lessons learned for teaching such courses; the sixth paragraph gives a conclusion on the applicability of the social practice perspective for learning processes in a RwL or similar lab setting, and its theoretical relevance.

\subsection{RwLs and the Role of Learning}

RwLs are a new format of transdisciplinary and transformative research. Initially conceptualized to address the need for "scientifically designed spaces of collaborative sustainability research involving intervention" [1] (p. 512), they have subsequently been defined based on first practical experience along seven key characteristics: 1. research-orientation, 2. normativity, 3. transdisciplinarity, 4. transformative approach, 5 . inclusion of civil society, 6 . long-term orientation, and 7. lab character [2,3]. Subsequently, this last point-the role of RwLs as a supportive structure to facilitate interventions, experiments, or transformative processes-has gained interest. It led to the following definition of an RwL which is used in this paper because it already includes educational goals and a notion of experimental/reflexive learning as part of the RwL:

"Real-world Laboratories (RwLs) are institutionalized interfaces between science and society. They offer a framework to address goals relating to research, practice and education. Their approach is transformative and follows goals that are socially legitimated, ethically founded and oriented towards the common good. Design principles for RwLs provide spatial, temporal, and topical orientation and support the role-constellation of actors, adequate for the transformative processes that need to be addressed. In RwLs, transdisciplinary projects (especially real-world experiments) can take place. Following an experimental and reflexive mode of work, they get reassessed and adjusted continuously" ([4], p. 78, own translation)

RwLs create a hybrid space between academia and other spheres of society, to facilitate practical change at the same time as gaining insights into transformation and enabling learning processes. The normative basis of RwL research is typically the goal of sustainable development, but other accepted societal frameworks can be addressed in an RwL as well, such as human rights issues, and its processes are oriented towards deliberative democratic ideas, esp. participation. RwL research is often seen as a methodology for transformative science [5], but it draws from other discourses as well, such as transdisciplinarity, intervention studies, transition management and urban planning [6]. In the understanding applied in this paper, RwLs are a transdisciplinary methodology with a transformative aim. Learning has been one of the early notions in the development of the RwL approach [7], relating to new social practices and double-loop learning, but initially not as a core concept.

A deeper discussion started in 2015, conceptualizing transformative experiments as a function of a learning society [8] and discussing RwL as a framework for such sustainability transitions. While this argument took learning to the level of society as a whole and showed the interrelation between individual and societal learning, the practical conclusions on how RwLs were supposed to support such learning methodically stayed vague. The integration of learning theory and didactical concepts was marked as a blind spot of methodological development [3] (p. 7) while the relevance of concepts such as social learning [2,9] and learning cycles [10] have been emphasized further. In 2018, also the empowerment of change agents and capacity building have been suggested as key components of an RwL [10], pointing out the integral role of learning in a transformation process. RwLs have also been described to give opportunity to develop "transformative literacy" [11].

Several authors have published experiences with teaching and learning in RwLs. Albiez et al. present first experiences with a "children's university" module, also emphasizing their own learning processes as RwL team [12,13]. West et al. describe how student-designed mobile interventions can stipulate critical reflection and mutual learning between stakeholders, integrating different types of knowledge and traditions of thought [14]. A prototypical sustainability learning lab in the Seychelles has been introduced as an example of an RwL that is methodically based on four interrelating teaching formats and pays close attention to intercultural communication [15]. 
Learning processes in RwLs have also been used as a point of comparison between RwLs [9]. Using the transitioning approach, parallel projects in four RwLs have been conducted that took learning serious as an aim: In each, the learning intentions of the actors involved have been explicated [16]. A comparative study on three RwLs identified two characteristic fields of tension regarding learning, "active experimentation vs. reflective observation and concrete experience vs. abstract conceptualization" [17] (p. 57). A first impulse for a systematic discussion of the educational potential of RwLs differentiated individual learning, social learning, and inter- and transdisciplinary cooperation [18], following a distinction from educational sciences originally describing sustainability studies in general. The same paper suggests an understanding of RwLs as "learning environments" $[19,20]$, linking it closely to the distinction used here of the RwL as a supportive framework for transdisciplinary activities therein.

\subsection{RwLs between Urban Transition Labs and Urban Living Labs}

RwLs represent one approach, with a strong basis in German-speaking countries, in a broader and international turn to laboratory-like settings both in (social) sciences [21] and experimental governance [22]. The emergence of such intermediate spaces at the junction of science and society can be traced back to heated conceptual discussions on post-normal science [23], mode-2 science [24] and earlier on the 'finalization' of science [25]. Here, two further concepts closest to RwLs are presented, Urban Living Labs and Urban Transition Labs. These terms are sometimes used as alternative translations for the German "Reallabor", and these approaches might still get integrated into one framework [26]. Learning and education have been discussed in the discourses on Urban Living Labs (ULLs), Urban Transition Labs (UTLs) and RwLs, but so far there have been few interconnections between them.

ULLs-conceptually an up-scaling of the user/customer-centered approach of living labs [27] —have been characterized along similar criteria as RwLs: Voytenko et al. list experimentation and learning as a characteristic of ULLs, along with geographical embeddedness, participation and user involvement, leadership and ownership, and evaluation and refinement [28]. ULLs constitute a framework for co-creation, but in a rather holistic and non-specific way as "urban innovation ecosystems" [29]. Even though the normative link to sustainability is often present, there is no systematic way of addressing implicit normativity, e.g., the implicitly modernist notion of "innovation". ULLs have been described as linked regional networks of various actors that are "systematically engaged in interactive and collective learning through an institutional milieu characterized by social embeddedness" [30] (p. 23). The notion of learning as a key characteristic is shared by other authors, but using varying concepts, e.g., learning platform [29] or iterative learning [31]. Learning has been identified as an aim of ULLs, e.g., [32], emphasizing the importance of formalizing knowledge production and exchange to enable both learning and scaling. The potential for formal learning has been pointed out, arguing that both cooperating with users and stakeholders in complimentary projects and the focus on iterative learning cycles are ideal starting points for higher education, "joining up the institutional response to sustainability challenges and engaging students in focused and applied projects that clearly contribute to a longer term, bigger picture of sustainability" [33] (p.4). Finally, learning has been discussed in the ULL discourse as one type of action to be taken in a broader transformative governance approach. Bukeley et al. argue for a shift from addressing ULLs "only as a means through which new kinds of research, development and learning are being orchestrated towards an assessment of how they serve to (re)configure socio-material conditions and mobilize agency and resources" [34] (p. 16). From this perspective, learning is one integral element in this governing strategy.

The discussion on UTLs started with one central paper, defining an UTL as "a hybrid, flexible and transdisciplinary platform that provides space and time for learning, reflection and development of alternative solutions [ ... ] The UTL concept meets this need [of cities] via the creation of a learning environment, which focuses on building reflexive, and entrepreneurial capacity as well as structuring 
knowledge for action" [35] (p. 115f). However, UTLs are currently also conceptualized rather as a process then as a laboratory.

UTLs are based on Transition Management, a multi-level governance strategy for sustainability transitions. It "[ ... ] shapes processes of co-evolution, using visions, transition experiments and cycles of learning and adaptation" [36]. This leads to a process understanding of UTLs: "Based on a number of essential assets of the transition management approach, an 'Urban Transition Lab' is the metaphor for a deliberate and identifiable process of systemic change towards sustainability, anchored in a city context" [37]. Transition experiments in the UTL are considered integrated "searching and learning processes (doing by learning and learning by doing)" [35] (p. 119)—such experiments can only be considered failures if nothing could be learned from them. Several authors argue that not only first order learning (within a given framework of values, problem definitions etc.) but also second-order learning (which changes the framework and concepts to describe the issue at hand, [38]) should take place in an UTL, an aspect often hindered by project restrictions, posing "an important barrier for scaling up learning experiences" [35] (p. 120). Even though not explicitly, some authors also address highly personal learning processes the actors engaged in the UTL face, e.g., when putting the "position and mode of science and researches" [35] (p. 121) in question and describing the working spirit in an UTL as "be-the-change-you-want-to-see-attitude" [35] (p. 120).

A transition experiment has been described as "an innovation project with a societal challenge as a starting point for learning aimed at contributing to a transition" [39] (p. 58). This implies an instrumental perspective on learning: "the objective of a transition experiment is contributing to a specific transition and the main means for this is learning" [39] (p. 58). The author also emphasizes the changing effect the learning process can and should have on the niche it takes place in. In accordance with the transition management cycle [40], Nevens and Roorda see (continuous) reflection and learning in close relation to monitoring and evaluation, establishing "cyclical learning" [37] (p. 113) over several transition cycles (see also [41]).

The discourses on ULLs, UTLs and RwLs show many similarities, especially in their positive, multiple, and unspecific use of learning. Notions of learning vary in several dimensions:

- Their function as goals, as means or as a characteristic,

- the mechanism of learning (e.g., experience, exchange-but never instruction),

- the model of learning (e.g., learning cycles, second-order learning),

- the role of the lab (as learning environment, learning institution, or experimental cycle).

The underlying constellation (e.g., individual, person-object, group-group, learning institution) and the multiple roles of the lab team (e.g., as experts, co-designers, facilitators, teachers) are hardly discussed at all, at least in relation to learning processes. Even papers applying a systematic from educational sciences [18] find a terminology to characterize some, but not all these distinctions. Table 1 shows key terms and short citations from all three discourses illustrating the similar spectrum of notions of learning in RwLs, ULLs, and UTLs.

Based on this overview, the following description of learning in a lab can be derived: A lab offers a learning environment for different actors, jointly engaging in a real-world issue, the lab supports cyclical learning processes that combine different forms of learning. However, this definition can only serve as a minimum consensus, not as a strong basis for analysis. 
Table 1. Notions of learning in the discourses on RwLs, UTLs, and ULLs.

\begin{tabular}{|c|c|c|c|}
\hline & Real-world Labs (RwLs) & Urban Transition Labs (UTLs) & Urban Living Labs (ULLs) \\
\hline \multicolumn{4}{|l|}{ Learning as a ... } \\
\hline Goal & $\begin{array}{l}\text { Address goals relating to research, } \\
\text { practice, and education [4] (p. 78), } \\
\text { transformative literacy [11] }\end{array}$ & $\begin{array}{l}\text { "building reflexive and } \\
\text { entrepreneurial capacity" [35] }\end{array}$ & \multirow[b]{2}{*}{$\begin{array}{l}\text { Key criterion: experimentation } \\
\text { and learning [28] }\end{array}$} \\
\hline Means & $\begin{array}{l}\text { Empowerment of change agents } \\
\text { [10] }\end{array}$ & $\begin{array}{l}\text { "the objective of a transition } \\
\text { experiment is contributing to a } \\
\text { specific transition and the main } \\
\text { means for this is learning" [39] } \\
\text { (p. 58) }\end{array}$ & \\
\hline \multicolumn{4}{|l|}{ Forms of learning } \\
\hline Exchange & Social learning $[2,9]$ & Social learning [39] & $\begin{array}{l}\text { Interactive and collective learning } \\
\text { [30] }\end{array}$ \\
\hline Reflection & $\begin{array}{l}\text { Experimental and reflexive mode } \\
\text { of work [4], Field of tension: } \\
\text { active experimentation vs. } \\
\text { reflective observation [17] }\end{array}$ & $\begin{array}{l}\text { "provides space and time for } \\
\text { learning, reflection and } \\
\text { development of alternative } \\
\text { solutions" [35] }\end{array}$ & \\
\hline Experience and action & \multirow{2}{*}{$\begin{array}{l}\text { Field of tension: concrete } \\
\text { experience vs. abstract } \\
\text { conceptualization [17] }\end{array}$} & $\begin{array}{l}\text { "searching and learning processes } \\
\text { (doing by learning and learning } \\
\text { by doing)" [35] (p. 119) }\end{array}$ & Applied projects [33] \\
\hline Abstraction & & $\begin{array}{l}\text { "structuring knowledge for } \\
\text { action" [35] }\end{array}$ & $\begin{array}{l}\text { Projects "contribute to a longer } \\
\text { term, bigger picture of } \\
\text { sustainability" [33] (p. 4) }\end{array}$ \\
\hline Combined forms & $\begin{array}{l}\text { Double-loop learning [7], learning } \\
\text { cycles [10] }\end{array}$ & $\begin{array}{l}\text { Cycles of learning and adaptation } \\
\text { [36], second-order learning }\end{array}$ & Iterative learning [31] \\
\hline \multicolumn{4}{|l|}{ Role of the lab as... } \\
\hline Learning environment & Learning environment [18] & Learning environment [35] & $\begin{array}{l}\text { Urban innovation ecosystem [29], } \\
\text { "institutional milieu characterized } \\
\text { by social embeddedness" [30], } \\
\text { learning platform [29] }\end{array}$ \\
\hline
\end{tabular}

\subsection{Analytical Perspective and Research Questions}

In sight of this less than ideal state of the three 'lab'-discourses, this paper takes a different approach. It shifts from typical management and structural perspectives to a user perspective. This perspective takes the RwL as a whole as a supportive infrastructure, into which the learning-oriented activity can be embedded. From this point of view, a holistic understanding of the contributions of an RwL is necessary, rather than one predefined by a specific concept of learning. Such a view needs to include the material and virtual learning environment, the social relations facilitated through the $\mathrm{RwL}$, and the knowledge, ideas, and skills an RwL and its team can provide in the process (even in the form of instruction). The contributions from all other groups need to be taken into account symmetrically. This is the reason to introduce social practice theory as an analytical perspective, following its early mentioning in the RwL discourse [7]. A similar approach has been suggested [42] to address the inconsistent notions of learning identified in the discourse on transdisciplinarity, using situated learning theory as basis to map out the social practices of learning in field-stay-based transdisciplinary courses.

This way, the following research questions can be addressed: 1 . Is social practice theory suitable to describe processes that integrate transformational, scientific, and educational aspects in a lab setting? 2. If yes, how does the RwL interrelate with learning processes in it in terms of social practice? The answers will be drawn for two contexts: Lessons learned for the practical application in similar teaching formats (paragraph 5), and a theoretical conclusion for the discourses on RwLs and similar types of labs (paragraph 6). 


\section{Methods: Social Practice Theory as a Qualitative and Semi-Quantitative Analytical Framework}

Social practice theory offers a medium scale understanding of social interaction (including interaction with the material world) and change. It is a well-established framework [43] which has produced numerous case studies [44] and aims at contributing to various fields of sustainability-related research, e.g., [45]. Its key assumption is that neither individualistic nor large-scale theories will cover social practices such as doing laundry [46], drinking habits [47] or sustainable energy consumption [48], even though this intermediate level of practices is highly relevant for initiating sustainability transitions [49]. To describe, analyze and potentially influence such practices, social practice theory addresses three analytical dimensions separately:

- "Images" refers to any type of meaning, knowledge, ideas, values, and concepts of identity.

- "Skills" refers to the abilities different actors require for a certain practice, both regarding social expectations and the handling of stuff.

- "Stuff" refers to the material world, manufactured artefacts and natural objects relevant in a practice.

Social practices are carried out not individually, but with larger groups of people interconnected by the social practice, but potentially in different roles, which is a point of special interest in the RwL discourse [50]. For the analysis presented here this is framed as a fourth aspect:

- "Networks", referring to the people included and their interrelations.

Social practice theory is fundamentally about change (e.g., towards more sustainable social practices), about the development of new and ending of old social practices. These changes require the development of new images, training of new skills, creation of new (or redefining of old) stuff, and the formation of networks. Learning is therefore a key part of social practice theory, especially regarding images and skills, commonly discussed [48] but not yet developed into an analytical aspect in its own right. As social practice theory is mostly used as a qualitative perspective, its semi-quantitative methodological use will be described in more detail.

\subsection{Qualitative Analysis Strategy}

This paper presents a qualitative description of all six Transdisciplinary Project Courses (TPCs) and the RwL they were embedded in. The qualitative analysis uses the social practice perspective both as a heuristic to reflect the cases multi-dimensionally and as a terminology for comparison and integration. It is based on field notes, standardized student evaluation questionnaires (esp. answers to open questions), notes from reflexive focus groups at the end of the courses, and interview-results generated in a master-thesis related to the last of the six TPCs [51]. The description of the RwL is based on the authors experience in the RwL and in the design of several projects in it. The qualitative analysis follows the organizational architecture of the RwL, interpreting it in terms of social practice.

In the context of higher education for Sustainable Development in RwLs in general, the four levels of social practice can be specified to some extent regarding the type of possible contributions from an RwL:

- Typical "images" contributed by the RwL encompass scientific notions of sustainability, participatory and transdisciplinary concepts, and notions of transformation, as well as knowledge generated in the RwL in earlier projects and local knowledge. Some impulses, initiated e.g., through good questions in a Socratic discourse with the students, can only be described qualitatively.

- Typical "skills" include teaching techniques, and transdisciplinary project management, ranging from purely practical matters to highly sophisticated contributions. The skills also include the ability to further the collaboration with other partners [52]. Some skills are "emergency"-skills, e.g., for mediating a conflict between students and practice partners, or skills to address suspected 
plagiarism. These skills are rarely used, but already the knowledge of their presence can be crucial. Again, this aspect cannot be quantified and can only be covered qualitatively.

- The infrastructure of the RwL is an essential part of the relevant "stuff". Online resources can also be treated as stuff, since virtual participatory tools can be used in a similar way as material ones. Apart from these specific tools, an RwL can create a creative or reflexive atmosphere for the participants which cannot be easily quantified.

- The relevant "networks"-contribution by an RwL is e.g., the initial contact to a practice partner and to a higher education partner. Beyond that, an RwL typically has a broad network of potential additional partners from civil society, local businesses or public bodies, e.g., the city administration. In a well-established RwL, other actors will already know about it even though there has been no direct contact before, making it easier to initiate a new cooperation.

\subsection{Semi-Quantitative Analysis Strategy}

To analyze the six cases semi-quantitatively, the four social practice dimensions have been quantified, based on the same data as the qualitative analysis. The contributions from students, practice partners and the RwL have been mapped out for each phase in each course separately. All contributions have been quantified by the author, who has been co-teacher in all six case studies, in retrospect. The contributions have been evaluated on the scale described in Table 2.

Table 2. Levels of relevance of contributions to the Transdisciplinary Project Courses.

\begin{tabular}{ccc}
\hline Level of Relevance & Quantification & Description \\
\hline No relevance & 0 & No contributions or fruitless contributions \\
Minor relevance & 1 & Singular and minor contributions to at least one student project \\
Major relevance & 2 & Contributions relevant to several groups or several contributions \\
High relevance & 3 & Contributions essential for the projects as a whole \\
\hline
\end{tabular}

The semi-quantitative data generated this way have been integrated over the six cases. The full dataset is accessible in a chart as Supplementary Data File [Table S1], along with several integrated charts based on it. For analysis, the dataset has been visualized in two diagrams showing the relevance of images, skills, stuff, and networks for the six phases of TPCs (Figure 1), and the contributions in terms of social practice theory in relation to the three main contributors: students, practice partners and the RwL, also along the phases of a TPC (Figure 2). No further separation of the role of RwL team members and the RwL was made (e.g., regarding the role as co-teachers, care-takers of the RwL infrastructure and as experts) because it was not feasible for the cases discussed here, even though this distinction might prove relevant in other cases. 


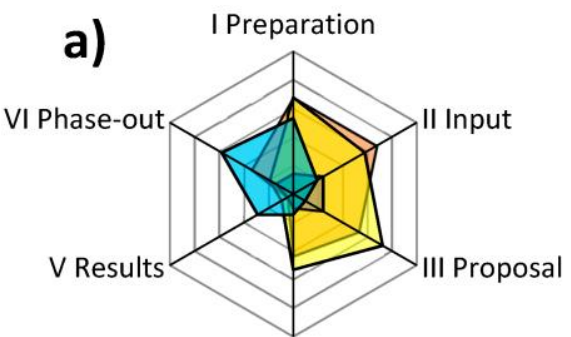

IV Project-work

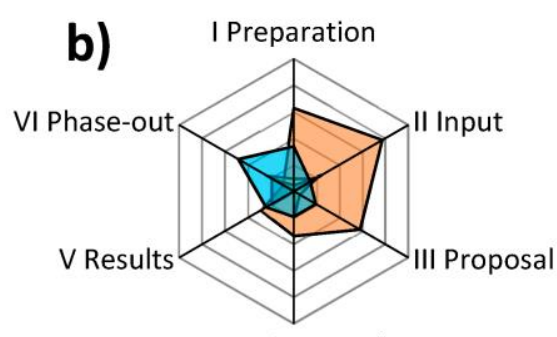

IV Project-work

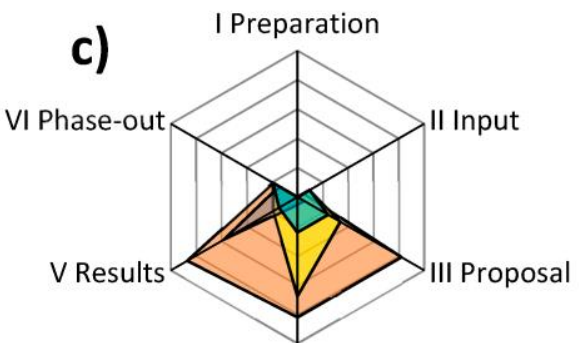

IV Project-work

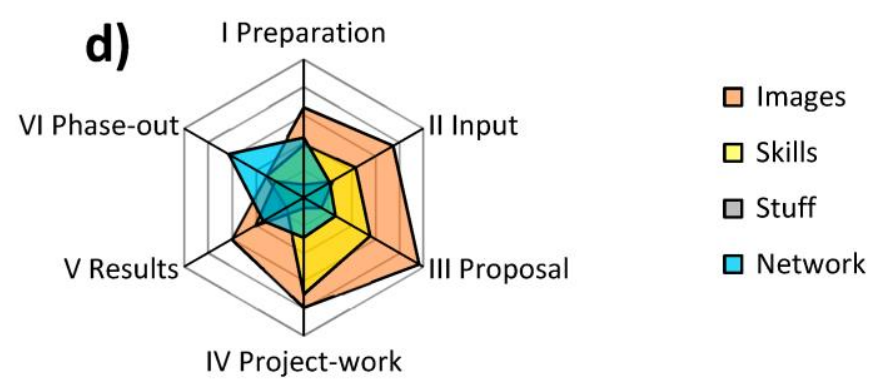

IV Project-work

Figure 1. Contributions of social practice dimensions along the phases of a TPC for (a) RwL; (b) practice partners; (c) students; and (d) all (sum of $\mathbf{a}-\mathbf{c}$ ).

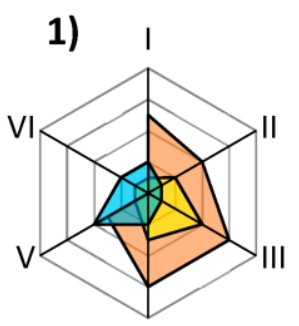

IV

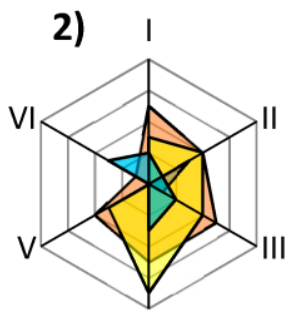

IV



6)



IV
5)

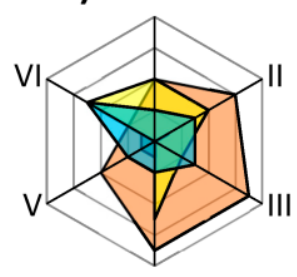

IV

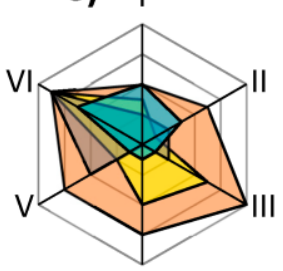

IV $\square$ Images

$\square$ Skills

$\square$ Stuff

$\square$ Network

Figure 2. Contributions along the phases in all social practice dimensions for each TPC 1-6.

\subsection{Transdisciplinary Project Courses}

As the analysis systematically follows the phases of the TPCs, their structure needs a brief introduction. TPCs are a teaching format developed in the Karlsruhe School of Sustainability-one of the projects forming the RwL-to establish a line of higher education courses embedded into the RwL. For students, they are part of the complementary qualification course on Sustainable Development at the Centre for Applied Humanities and General Studies at KIT. TPCs are designed for up to 24 students from all disciplines offered at KIT, with at least some basic knowledge of sustainability. They include a practice partner, typically from civil society initiatives, sometimes as official co-teachers.

The TPCs are based on transdisciplinary methodology, reinterpreted for an educational context (for this strategy, see [53]). They are inspired by the ETH case study methodology [54,55], but on a smaller scale and with more freedom of choice for the participating students. TPCs include aspects of service learning, learning by research, team teaching and reflexive learning. TPCs also show similarities 
to the challenge lab approach at Chalmers University $[56,57]$. The timeline of the courses is structured in six phases (Table 3), including preparation and a phase-out which can often be crucial for the success or failure of transdisciplinary projects [58]. In Phase III-V, students form teams working in parallel on projects of their own choice, to allow for mutual learning between them. Table 3 gives an overview on key tasks in all phases.

Table 3. The six phases in a transdisciplinary project course.

\begin{tabular}{|c|c|}
\hline Phase & Key Tasks \\
\hline I. Preparation & $\begin{array}{l}\text { - } \quad \text { Identifying a potential CSO partner from the RwL-network } \\
\text { - } \quad \text { Clarifying roles, expectations, addressing time-restrictions } \\
\text { - } \quad \text { Establish team-teaching partnership, ideally with practice partners } \\
\text { - } \quad \text { (Normal preparation for HESD) }\end{array}$ \\
\hline II. Introduction & $\begin{array}{l}\text { - Introducing students to the sustainability aspects of the topic, the CSO partner and its } \\
\text { needs, and the project methodology } \\
\text { - } \quad \text { Reflexive and mutual clarification of the students' interests and goals }\end{array}$ \\
\hline III. Proposal & $\begin{array}{l}\text { - Mapping out potential projects based on analytical, practical, and educational goals } \\
\text { - } \quad \text { Forming student teams } \\
\text { - } \quad \text { Preparation of project proposal } \\
\text { - Decision on the proposals with practice partners }\end{array}$ \\
\hline IV. Project work & $\begin{array}{l}\text { - } \quad \text { Self-organized project work in small teams } \\
\text { - } \quad \text { Regular exchange between teams on overarching issues and possible synergies } \\
\text { - } \quad \text { mentinuous supervision by teaching team, offering mediation, input, and } \\
\text { methodogical suggestions }\end{array}$ \\
\hline V. Results & $\begin{array}{l}\text { - } \quad \text { Presentation of results, handing over material results } \\
\text { - } \quad \text { Reflection and evaluation of the learning process } \\
\text { - } \quad \text { Debrief between practice partners and RwL team (if feasible) }\end{array}$ \\
\hline VI. Phase-out & $\begin{array}{ll}\text { - } & \text { Finalizing unfinished elements } \\
\text { - } & \text { Stabilizing practical results, transfer of ownership } \\
\text { - } & \text { Analytical documentation (such as this paper) } \\
\text { - } & \text { (General teaching tasks, e.g., grading of project results) }\end{array}$ \\
\hline
\end{tabular}

In relation to the notion of learning (Table 1), TPCs treat learning as a goal, along practical transformation and scientific insights, using the RwL as a learning environment. They combine instruction, active engagement, reflection, and exchange (between individuals, between student teams and with practice partners and co-teachers). Abstraction usually takes place related to the reflection and transferability of results. As part of the complimentary qualification course, students get a chance for iterative learning cycles, but some of the students participate only in this single supplementary class. In Phase I and II, the different actors, their images (interests and ideas) need to be integrated. In Phase V and VI, the threads of the educational process (centered around the students), the practical process (typically centered around the CSO partners) and the scientific process (typically centered around the RwL team) need to be disentangled, a common element in schematics of transdisciplinarity in general [59] or RwL research specifically [10].

Table 4 gives an overview on the TPCs conducted so far. 
Table 4. The six Transdisciplinary Project Courses.

\begin{tabular}{|c|c|c|}
\hline Course Title (Translated) & CSO Partners & Issues Addressed by Student Teams \\
\hline Better Life at higher age in Karlsruhe & Parish initiative "good aging" & - $\quad$ Emergency buttons \\
\hline Dinner is served! & Foodbank Karlsruhe & $\begin{array}{l}\text { - Waste management } \\
\text { - Food storage }\end{array}$ \\
\hline Repair, reuse, do-it-yourself & RepairCafé initiative Karlsruhe & $\begin{array}{ll}\text { - } & \text { Internal management } \\
\text { - } & \text { Image film } \\
\text { - } & \text { Lest practice in Germany business partners } \\
\text { - } & \text { Cooperation with schools }\end{array}$ \\
\hline $\begin{array}{c}\text { Economy of the common good for } \\
\text { Karlsruhe? }\end{array}$ & $\begin{array}{l}\text { Economy of the Common Good } \\
\text { (ECG) initiative, Karlsruhe }\end{array}$ & $\begin{array}{ll}- & \text { Notions of 'trust' } \\
- & \text { ECG info film } \\
- & \text { ECG for CSOs } \\
\text { - } & \text { Local businesses' view on ECG }\end{array}$ \\
\hline $\begin{array}{l}\text { Planning higher education for sustainable } \\
\text { development }\end{array}$ & $\begin{array}{l}\text { Center for Applied Humanities } \\
\text { and General Studies, KIT }\end{array}$ & $\begin{array}{ll}\text { - } & \text { Personal sustainability } \\
\text { - } & \text { Sustainability and water } \\
\text { - } & \text { Course concept }\end{array}$ \\
\hline Sustainability city walk Karlsruhe & $\begin{array}{c}\text { Stattreisen e.V., } \\
\text { city of Karlsruhe, } \\
\text { Global Consortium for } \\
\text { Sustainability Outcomes }\end{array}$ & $\begin{array}{l}\text { Sustainability city tour as: } \\
\text { - } \quad \text { Brochure } \\
\text { - } \quad \text { Guided tour } \\
\text { - } \quad \text { Online map } \\
\text { - }\end{array}$ \\
\hline
\end{tabular}

\section{Qualitative Analysis}

\subsection{The RwL "District Future-Urban Lab" as a Framework}

The RwL "District Future-Urban Lab" in Karlsruhe is comprised of several projects, only one of them explicitly termed a Real-world Lab. The overarching goal is to become a driver for the transition of one city district in Karlsruhe/Germany, the "Oststadt", towards more sustainability with a focus on cultural and social aspects [60]. The intervention strategy covers a broad spectrum from low-threshold encounters with citizens to long-term co-design and co-creation projects [61], especially with civil society partners such as the RepairCafé Karlsruhe [62]. The architecture of the RwL "District Future" distinguishes three levels: (a) transdisciplinary projects and events; (b) continuous scientific tasks; and (c) infrastructure and organizational tasks. While (a) describes the experiments and other, smaller intervention formats; (b) and (c) describe the RwL and the tasks necessary to keep it running. These three levels can be reflected in terms of social practice:

(a) Transdisciplinary projects and events. This element encompasses three project-based formats: (1) Co-designed and science-lead transdisciplinary projects on key sustainability issues which had been identified in a broad participatory process in the district; (2) A competition and facilitation format for science inspired, community-based sustainability experiments [63]; and (3) the TPCs presented here. Apart from transdisciplinary projects, numerous continuous, regular, and single events take place in the RwL, such as clothes-swap parties, exhibitions, presentation and discussion events, or consultation e.g., on sustainable multimodal mobility. Not all these activities are carried out by the RwL team. Some are not even initiated by the RwL but through various interested groups and individuals, forming together a hub for local sustainability culture.

In the transdisciplinary projects and regular events, all social practice dimensions are relevant. While each project can include different images, skills, stuff and networks, the notion of sustainability 
serves as an integrative image, transdisciplinary practices are a key element of the skills employed, and even though different actors are involved in the activities, the whole network of the RwL stays at least informed.

(b) Continuous scientific tasks. The continuous tasks required in the RwL relate to (1) monitoring and sustainability assessment; (2) keeping the local network active (e.g., participation in events from CSO or city partners); (3) taking part in the scientific exchange, including posing as a case study for comparative studies and (4) linking RwL activities to higher education and public science, e.g., through guest lectures and courses hosted in the RwL. The link to higher education also facilitates reflection (e.g., research colloquia) and outreach (e.g., interns, groups of visitors, guest lectures). Through a social practice lens, the continuous tasks require primarily transdisciplinary scientific skills and management skills. Again, the idea of sustainability has an integrative function. Engaging in networks is not so much a dimension of this level, but an explicit task.

(c) Transdisciplinary infrastructure. The city district "Oststadt" the RwL is working in (and working with) forms the real-world basis for the RwL. The district takes the form of a Real-world Lab through the transdisciplinary infrastructure embedded into it. The central element of this infrastructure is the "Future Space for Sustainability and Science" (FutureSpace), a former local shop in the middle of the Oststadt, with flexible rooms for the tasks described in (1) and (2) as well as some office space and a tiny kitchen. In it, various participatory tools are ready for use (e.g., large maps, an interactive fotobox, a cargo bike, information material on various sustainability issues). Several of the CSO partners use the FutureSpace regularly and share related responsibilities. Apart from the FutureSpace, the online communication infrastructure (interactive map, blog, and newsletter) and the necessary non-content related project management (e.g., finances, lists of partners) are part of the infrastructure. While the RwL has been evolving since 2012 in terms of images, skills, and networks, the FutureSpace was ready only in 2015, in time for the third TPC.

The Oststadt as a real-world setting includes numerous social practices; relevant for the RwL are the CSOs and individuals interested in sustainable development as a local network, material elements (such as squares, the congested traffic, or urban gardens) as stuff. Skills and images are only insofar part of the infrastructure as they are required to keep the infrastructure functional or plan new elements.

It is important to note that the RwL follows a whole institution approach to participation, as far as possible under current institutional and funding restrictions, which has a transformative potential in itself: The RwL in Karlsruhe is not meant to be imposed on the district but must become a living part of it. The integration of higher education in the RwL also serves as a link between the often parallel life-worlds of students and local citizens in the Oststadt.

\subsection{Course 1: Better Life at a High Age in Karlsruhe}

This first course took place in cooperation with one of the early practice partners in the RwL (at that time still in development), a parish initiative to support the elderly in the neighboring districts, and a very small group of students. This course served as a prototype for the course structure, which was formalized only afterwards. Some weeks into the course, the cooperation pattern with the CSO partner changed, when they introduced one topic they needed support on, an information event on emergency buttons. From this point on the practical goals were predefined, and a primarily service learning-oriented approach evolved. It proved valuable to offer a final reflexive meeting only with the students to reflect the shift in goals and roles. In terms of networks, the students brought in an additional partner, a commercial provider for emergency buttons, and the practice partner informed local elderly citizens with moderate success. In terms of images and skills, students drew from their personal experience and ideas, the RwL contributed methodological skills and images about social sustainability. The stuff relevant in the project came from different partners, the parish meeting hall, information material from the students, and a demonstration kit from the commercial partner. 


\subsection{Course 2: Dinner is Served}

The second course was a cooperation with one of the food banks in Karlsruhe on sustainable ways of handling surplus food. After accepting that the course was not (primarily) a recruiting event for the practice partner, a critical discussion on the role and appropriateness of food banks evolved, leading to two projects on food storage information for customers and on waste management. The latter proved to be analytically demanding but lead to the practically unspectacular result that the existing system was nearly ideal. The standardized evaluation of the course, carried out at the beginning of the project phase, put a spotlight on the disorientation that can occur in an open project, leading to critical results. Again, reflexive interventions with the students were crucial to identify what unspoken expectations (e.g., of project management, of teaching roles) were at play. The focus-group evaluation at the end of the course showed a far more positive result, but nevertheless raising questions on practical relevance vs. scientific quality of the projects. This experience lead to clarifying the expectations in terms of educational, practical, and analytical goals well in advance, both from the co-teachers and the students. In terms of images, all partners contributed, the students with a very broad variety of knowledge from their studies. In terms of skills, the two student projects differed widely: One was highly analytical, the other one purely practical, causing some friction between the student teams. The whole group was invited to visit the food bank in the preparation phase of the course, which gave them contact to the relevant stuff (cooling equipment and waste treatment). In terms of networks, the practice partner was reluctant to invite the students to their customers to avoid irritating them. Students brought in two other actors, whose engagement stayed minimal, but who contributed valuable information.

\subsection{Course 3: Repair, Recycle, Do-It-Yourself}

The third course addressed alternatives to consumerism, in cooperation with a RepairCafé Initiative as practice partner. This initiative had initially formed through a repair-event from the RwL and has been a partner since [62]. The initiative was at the time in the process of forming a registered association - an important step due to major related insurance issues in German law. The initial hope of the CSO partners to address these insurance issues directly has not been met, due to the lack of legal competencies among the participating students. Nevertheless, the students were able to produce several useful contributions, e.g., an image film enhanced online visibility, an internal management game addressed issues the planned CSO might face, and a flyer for customers of the repair cafe gave a map for local shops selling spare parts. In terms of images, all partners engaged in an exchange with contributions from all sides. The skills students applied varied between the projects from very analytical (e.g., a comparative case study approach) to very practical (e.g., filming). Students and the RwL team contributed new network partners. In terms of stuff, it was the first course that could use the "FutureSpace" as infrastructure, and some of the student teams produced material results.

\subsection{Course 4: Economy of the Common Good (ECG) for Karlsruhe?}

The third course addressed sustainable business as core topic. With a representative of the ECG initiative as co-teacher and other members attending several of the seminar meetings, it was characterized by close cooperation. Assumptions of the students, that they were expected to leave their critical perspective on ECG aside had to be addressed directly. This critical view was afterwards included in two of four projects, constituting an interesting exchange of ideas (images). All students and the RwL team acquired at least basic skills of applying ECG. Being part of a larger network, the local ECG initiative put students in contact with experts on various aspects, broadening the relevant network. One project presented the first preliminary ECG-assessment of a CSO-organization, pointing out differences to businesses, as a contribution to this wider network. An information film produced in the seminar and shared online became-long after the course-one of the most-used German introductory resources on ECG, making it the most influential piece of stuff. The ECG initiative already used the FutureSpace for meetings, which made it a connecting element in the cooperation. 


\subsection{Course 5: Planning Higher Education for Sustainable Development}

This course with a small group of students served as a step in the planning process of a broad introductory course on Sustainability at KIT, in cooperation with the Center for Applied Humanities and General Studies. Seeing that the introductory course to be planned was intended as cooperation as well, the students did not distinguish between the RwL team and the practice partner. This did not jeopardize the cooperation but gave rise to repeated questions regarding the openness of the process and the difference in expectations in educational and practical terms. The images were all centered around sustainability and learning, in which the students also had knowledge to share. The skills of planning a course were contributed by the RwL and practice partner, but again the students had some relevant experience. Stuff played a minor role in this course, apart from the FutureSpace as infrastructure. This course profited from the scientific network of the RwL team.

\subsection{Course 6: Sustainability City Walk Karlsruhe}

The course had a complex architecture. It was linked to a larger scale, comparative project in the RwL on city-university partnerships [52], therefore involving representatives of five city departments, along with one CSO partner offering alternative city tours. Furthermore, the student teams regrouped. Until the proposal phase, they worked on different overarching issues such as potential addressees, the overall route, or applicable media. After deciding on these issues with the city partners, they regrouped to work on the chosen key locations on the route, gathering local and historical information, and linking it to the Sustainable Development Goals. During the process, the CSO partner became much more involved than expected, and took on ownership of the guided tour format permanently. This course needed an intense phase-out to finalize the results and to establish long-term ownership. All partners shared images about sustainability and local knowledge of Karlsruhe, even though the timing was not always ideal. The skills needed for the project were, apart from research and analytical skills, related to explaining complex issues in the form of a city tour, the key skillset of the CSO partner. The course produced results in the form of different stuff-partly virtual, partly material—which also became part of the RwL participatory tools. All partners contributed extensions of the network, which all stayed limited (as planned).

\section{Semi-Quantitative Analysis of the Six Transdisciplinary Project Courses}

Table 5 shows the relevance of all aspects of social practice-images, skills, stuff, and networks-aggregated for the six TPCs. The full dataset is published as Supplementary Material online [Table S1]. For easier discussion, the data is visualized in Figures 1 and 2.

Table 5. Contributions of the different actors involved, aggregated for six TPCs.

\begin{tabular}{|c|c|c|c|c|c|c|c|}
\hline & & $\begin{array}{c}\text { I } \\
\text { Preparation }\end{array}$ & $\begin{array}{c}\text { II } \\
\text { Input }\end{array}$ & $\begin{array}{c}\text { III } \\
\text { Proposal }\end{array}$ & $\begin{array}{c}\text { IV } \\
\text { Project } \\
\text { Work }\end{array}$ & $\begin{array}{c}\text { V } \\
\text { Results }\end{array}$ & $\begin{array}{c}\text { VI } \\
\text { Phase-Out }\end{array}$ \\
\hline \multirow{4}{*}{ RwL team } & Images & 14 & 14 & 11 & 9 & 1 & 7 \\
\hline & Skills & 14 & 12 & 15 & 11 & 2 & 4 \\
\hline & Stuff & 3 & 5 & 5 & 2 & 1 & 3 \\
\hline & Networks & 11 & 4 & 2 & 3 & 6 & 12 \\
\hline \multirow{4}{*}{ Students } & Images & 0 & 1 & 17 & 17 & 18 & 4 \\
\hline & Skills & 0 & 2 & 7 & 14 & 4 & 4 \\
\hline & Stuff & 0 & 0 & 1 & 1 & 12 & 3 \\
\hline & Networks & 0 & 2 & 5 & 5 & 3 & 4 \\
\hline \multirow{4}{*}{$\begin{array}{l}\text { Practice } \\
\text { partners }\end{array}$} & Images & 13 & 16 & 12 & 7 & 6 & 2 \\
\hline & Skills & 2 & 4 & 1 & 4 & 0 & 5 \\
\hline & Stuff & 1 & 5 & 0 & 0 & 4 & 4 \\
\hline & Networks & 7 & 3 & 4 & 4 & 5 & 10 \\
\hline
\end{tabular}


Figure 1 shows the contributions along the six phases of the TPC in terms of images, skills, stuff, and networks. In total (d), images have-not surprisingly for a higher education course-a high relevance throughout the process, least so in the phase-out. The relevance of skills grows to reach a maximum in the project work phase, dropping with the presentation of the results, a major shift in the style of working together that needs to be managed carefully. Stuff plays a minor role in the process, but rarely drops out completely, especially in the sense of the FutureSpace as a learning environment. Networks have highest importance at the beginning and the end of the TPC. This can be interpreted as the transfer of ownership; it also constitutes a steppingstone for further cooperation.

The integrated data $(\mathrm{d})$ show that, while all partners contribute to the processes, there are considerable differences in the type and timing of the contributions. The RwL and its team contribute from the beginning (a). The high skill contributions for phase I-IV can be understood as a double skillset: both the didactical skills of teaching the course and the transdisciplinary skills of finding the right approach for a topic are part of the overall skills. Holding back and giving students and practice partners space to discuss the results in phase $\mathrm{V}$ are not framed as a skill here. The images contributed in the beginning also represent an element of instruction, on the city, on the RwL, on sustainability in general and the specific topic. This mode of teaching then gives way to co-design in the proposal phase and even less images contributed in the project phase. The stuff contributed by the RwL keeps on a low level throughout, but indirect effects of the FutureSpace stay mostly invisible.

Practice partners (b) contribute mainly in terms of images, primarily in phase I-III. They have a strong potential to bring in other actors from their network at any phase of the TPC. Skills and stuff play a minor role. It is noteworthy that the stuff practice partners bring in is often related to their own premises (e.g., food bank) or events (e.g., RepairCafé). Students (c) are not part of the process in phase I, mostly receptive in phase II and only some remain active in phase IV, therefore student contributions take place almost only in III-V. They contribute images throughout, use their skills during phase IV. In some cases, the results presented are "stuff", but not always. Unexpectedly, students also brought in networks, even though on a lower level than the other partners. In some cases, students became members of the CSOs or-as student assistants-the RwL, blurring the role distinctions during phase-out. Looking at the sum of contributions, images are most important during the first phases, skills during proposal and project work, stuff in the phase of results and networks during preparation and phase-out.

A basis for the comparative analysis of the courses is shown in Figure 2. Here, the contributions from all stakeholders are aggregated for each phase in each course. The sum of these six charts is identical to Figure 1d. The six courses show considerable variation regarding the relevance of the social practice dimensions. While the dimension of images has the highest contribution in all courses, the intensity varies to some extent. Especially in course (6), there were still major contributions in this dimension during phase-out. The same can be seen in the other three dimensions, which can be interpreted as a course producing not entirely finished results. The timing and extent in which skills were contributed shows major differences between the courses, corresponding to different skillsets of the students taking part, different intensity of teaching skills required, and different transdisciplinary methodological contributions necessary for different projects. This dimension highlights the necessity to keep skills "on tap", a situation for which a diverse RwL team with broad experience and disciplinary background seems ideally suited. Networks were contributed at any phase in the TPC, typically with a maximum during phase-out, when ownership was passed on and roles and relations changed. The role of stuff was minor in all courses. Whether this is to be considered an unused potential of these courses-missing boundary objects, concrete locations, and tangible results—or whether the relatively higher importance of the other social practice dimensions is indeed adequate, would need to be assessed based on a spectrum of other cases. 


\section{Lessons Learned for Teaching in an RwL}

The timing of the TPCs proved to be a valuable structure to map out the findings about the courses and the way they were embedded in the RwL, therefore the lessons learned will be presented along these phases as well-assuming that other courses follow a similar time structure.

\subsection{Phase I. Preparation: Mutual Trust from the Beginning}

The recruiting of practice partners is mostly based on the existing RwL networks of local CSOs and other partners. This extremely helpful basis offers much more than an initial contact: The trust necessary to commit to the cooperation, the mutual understanding of the respective interests in the project, as well as seemingly trivial matters (How do group decisions work in the respective CSO?) play a central role. Also, the courses can be used for long-term cooperation strategies of the RwL. Practice partners can misinterpret the courses as recruiting event or a chance to pass predefined tasks to the students, these expectations need to be addressed in this phase.

\subsection{Phase II. Introduction: Sustainability and Transdisciplinarity as Key Images from the RwL}

During the introduction, RwL team members give input to the courses on the local situation in the district, on sustainability in general and on specific sustainability issues at stake in relation to the TPC. Some of this input is clearly instructional, a teaching style also expected from the students. It is necessary to show students the relation of the scientific interests of the RwL to the course topic. All scientific input requires transdisciplinary awareness, linking scientific concepts to the notions of the practice partners. Students can misinterpret the cooperation with practice partners as an expectation to put their critical thinking aside. Therefore, it is important in this phase to welcome critique and skepticism (e.g., regarding the appropriateness of food banks or the feasibility of an "Economy of the Common Good"), redirecting it into analytical questions to be addressed rather than into conflicts.

\subsection{Phase III. Proposal: Skills and Images on Tap in a Creative Learning Environment}

The proposal phase allows the students to explicate their ideas and gain feedback from practice partners and co-teachers, changing the dominant mode of learning and working from a receptive to an interactive and creative one. Defining realistic project proposals with balanced scientific, practical, and educational goals require transdisciplinary skills and images from the co-teachers and sometimes the wider RwL team. In this phase, the quality of the RwL as a learning environment with an atmosphere of creative cooperation and engagement for sustainability was most valuable. It offers flexible infrastructure for presentations, small-group meetings, and individual thought, and information from material and the RwL team is always at hand. This atmosphere can mislead students to take the course not entirely serious, which is already a risk for non-compulsory and interdisciplinary courses, or to work at a slower pace. Teaching the course in the district itself supports direct contact to stakeholders compared to a situation where practice partners must find their way into anonymous university buildings, but it can hinder student-student cooperation due to the location beyond the campus.

\subsection{Phase IV. Project Work: All in the Hands of Students}

During this phase, the RwL is just the backdrop. The process is almost entirely in the hands of the students, working on their projects, involving practice partners and co-teachers to the extent and in the way they consider necessary. Students make use of the networks, skills, stuff, and images of the RwL and the practice partners, but they can also choose not to. Only activities between student teams, facilitating mutual learning or identifying synergies, requires active intervention from the side of the co-teachers. Students and practice partners might assume that the RwL team will take over ownership of the results, therefore the long-term ownership for each of the planned results needs to be clarified in this phase at the latest. 


\subsection{Phase V. Results: Presenting to the Right Audience}

The presentation of results requires careful choice of location and of actors to be involved. The goal is to engage a broad audience from the respective practice partner, but also the RwL team and potentially other interested actors. During the discussion of the results, images from the RwL team provide valuable context to understand the scientific and practical relevance of the results.

\subsection{Phase VI. Phase-Out: Various Activities Call for Flexible Action}

Very different activities are required during this phase. Reflection of the process and evaluation require stuff in terms of a protected space, for which the RwL infrastructure is ideal. Dissemination of results can be based on the networks, skills and (virtual) stuff of the RwL. If results are linked to a practice partners internal activities, ownership must be passed on. The formulation of student papers, their marking and related exams are usually independent of the RwL. In several instances, changes and overlap of roles became visible in this phase, e.g., from teaching partner to addressee, or from student to CSO partner. While these changes are not problematic in themselves, overlooking them can cause friction due to misplaced expectations.

\section{Conclusions}

Regarding research question 1 , whether social practice theory is suitable to describe processes that integrate transformational, scientific, and educational aspects in a lab setting, the analysis shows that the social practice perspective can indeed shed light on the details of the process and its interrelation with the lab. Both in terms of project phases and in terms of actor groups involved, it provides a framework for mapping out contributions in a comparable fashion. Some effects remain too subtle (e.g., the "atmosphere" of the FutureSpace) or unquantifiable (e.g., mediation skills as an unused safety net), so that a qualitative perspective remains an important complementary perspective to the semi-quantitative approach. Including the dimension of networks helps to keep effects of different and changing roles in view. For future research, a refinement of the social practice perspective as an analytical tool seems feasible and promising regarding four aspects:

- Adopting a multi-stakeholder perspective, mapping out perceived relevance of contributions in the eyes of co-teachers, practice partners and students alike.

- Enhancing granularity by assessing not just each course, but each student project individually.

- Strengthening the link between qualitative and quantitative data on the TPCs in a specialized questionnaire.

- Including the social practice perspective into the design and evaluation of the courses.

To achieve a deeper understanding of the role of learning in RwLs and similar labs, it seems advisable to include more fundamental theories of learning. The notion of second-order learning, for example, has come up in various forms in the theory of learning, dating back to Piaget's concept of accommodation: changing mental frameworks of understanding, to make sense of new information that does not fit into the earlier framework [64]. Other links to educational theory might include an understanding of experience, experimentation, and abstractions in Wagenschein's didactics [65] or ethical considerations on learning and teaching already discussed by Kant [66].

Regarding research question 2, how the RwL interrelates with the learning processes, the general answer is that learning processes include all four dimensions of social practice, even though to varying degrees and with changing priorities over time. The semi-quantitative analysis shows a relatively high importance of images and skills from the RwL team, and a relatively small influence of "stuff". This corresponds to the qualitative finding that the influence of the RwL as a district to work in and the FutureSpace as a learning environment have subtle and indirect effects on the process. The qualitative and semi-quantitative finding that the importance of networks is most important for preparation (I) and phase-out (IV) emphasizes how the TPC can be used as one step in a sequence of cooperative formats. 
This paper focused on contributions from the RwL to the TPC. The contributions from the TPC to the RwL are to diffuse and slow to map out in a similar way, but some types of contributions can at least be named: On the level of images, student teams can unearth examples and theoretical approaches not known to the RwL team, this effect is stronger with students with diverse disciplinary backgrounds and practical experience in some related fields. Also, their critical view on often unquestioned assumptions in the RwL can contribute to adjusting the RwL as a whole. Depending on how public results are presented and used, they can become an element of the outreach of the RwL. On the level of skills, the RwL team develops a broad spectrum of teaching skills (e.g., instruction, advice, monitoring processes, and facilitating reflection) which correspond to the skills required to support participatory processes. On the level of stuff, the student project teams sometimes create results of high value as participatory tools for the RwL and keep the infrastructure (such as the FutureSpace, in our case) in use, alive and interactive. On the level of networks, the TPC can help stabilize an existing cooperation and build new ones, also between other stakeholders. Even if no permanent cooperation is built, a deeper knowledge of the actors in the field (or the lack of certain actors) helps to understand the possibilities an RwL has in its social context. Such network contributions sometimes pay off only years later.

Based on the integrated understanding of learning in labs, the findings presented here can be adapted for other labs as well: When an UTL focusses on one transition process rather than a multitude of interventions, the courses need to be built deeper into the whole methodology. This enhances the practical relevance and methodological rigor, while at the same time reducing the students' free choice. When transferring it to the more open innovation ecosystem of an ULL, "stuff" might gain more relevance, as well as the subtle influence of the lab as a learning environment. If social networks are not (yet) closely woven in the lab, issues of ownership need to be addressed very carefully. As with many project-based didactical concepts, the balancing of instructive, creative, experiential, and reflexive elements-along with the ability not to intervene too much—is difficult to achieve. A lab setting that exists before, after and beyond the project itself can support this didactical challenge, and profit from it, respectively.

Supplementary Materials: The following are available online at http:/ / www.mdpi.com/2071-1050/10/10/3798 / s1, Table S1: Contributions of practice partners, students and the RwL for all phases of six Transdisciplinary Project Courses (raw data and aggregated data for Figures 1 and 2).

Funding: This research received no external funding.

Acknowledgments: I thank Marius Albiez, Kaidi Tamm and Miriam Friedrichs and all representatives of CSO initiatives involved in the courses-it was a great experience working together with you. I thank André Reichel for introducing me the to the social practice perspective, and the reviewers for insightful suggestions to improve this text substantially. I thank the Centre for Applied Cultural Research and General Studies for handling the administrative side of the courses, including subsequent tests and certificates for students. I acknowledge support by the Ministry of Science, Research and the Arts for funding of the underlying teaching activities and the support by Deutsche Forschungsgemeinschaft and Open Access Publishing Fund of Karlsruhe Institute of Technology for the funding of publication fees.

Conflicts of Interest: The author declares no conflicts of interest. Neither the practice partners nor the founding sponsors had any role in the design of the study; in the collection, analyses, or interpretation of data; in the writing of the manuscript, and in the decision to publish the results.

\section{References}

1. WBGU (German Advisory Council on Global Change). Humanity on the Move: Unlocking the Transformative Power of Cities; WBGU: Berlin, Germany, 2016.

2. Parodi, O.; Albiez, M.; Beecroft, R.; Meyer-Soylu, S.; Quint, A.; Seebacher, A.; Trenks, H.; Waitz, C. Das Konzept "Reallabor" schärfen: Ein Zwischenruf des Reallabor 131: KIT findet Stadt. GAIA 2016, 25, $284-285$. [CrossRef]

3. Beecroft, R.; Parodi, O. Reallabore als Orte der Nachhaltigkeitsforschung und Transformation. Einführung in den Schwerpunkt. TATuP 2016, 25, 4-8. 
4. Beecroft, R.; Trenks, H.; Rhodius, R.; Benighaus, C.; Parodi, O. Reallabore als Rahmen transformativer und transdisziplinärer Forschung: Ziele und Designprinzipien. In Transdisziplinär und Transformativ Forschen. Eine Methodensammlung; Defila, R., Di Giulio, A., Eds.; Springer VS: Wiesbaden, Germany, 2018; pp. 75-100.

5. Scholz, R. The normative dimension in transdisciplinarity, transition management, and transformation sciences: New roles of science and universities in sustainable transitioning. Sustainability 2017, 9, 991. [CrossRef]

6. Parodi, O.; Beecroft, R.; Albiez, M.; Quint, A.; Seebacher, A.; Tamm, K.; Waitz, C. The ABC of real-world lab methodology-From "action research" to "participation" and beyond. TRIALOG 2017, 126, 74-82.

7. Schneidewind, U.; Scheck, H. Die Stadt als "Reallabor" für Systeminnovationen. In Soziale Innovation und Nachhaltigkeit; Rückert-John, J., Ed.; Springer VS: Wiesbaden, Germany, 2013; pp. 229-248.

8. Schneidewind, U.; Singer-Brodowski, M. Vom experimentellen Lernen zum transformativen Experimentieren. Zeitschrift für Wirtschafts und Unternehmensethik 2015, 16, 19-51.

9. Schäpke, N. Jointly experimenting for transformation. Shaping real-world laboratories by comparing them. GAIA 2018, 27 (Suppl. 1), 85-96. [CrossRef]

10. Wanner, M.; Hilger, A.; Westerkowski, J.; Rose, M.; Stelzer, F.; Schäpke, N. Towards a cyclical concept of Real-World Laboratories: A transdisciplinary research practice for sustainability transitions. disP Plan. Rev. 2018, 54, 94-114. [CrossRef]

11. Kraft, A. Application of Real-World Laboratories for the Sustainable Transformation of Urban Areas through Change Agents-Knowledge Generation, Analysis, Implementation and Transfer. Master's Thesis, University of Eberswalde, Eberswalde, Germany, 2017.

12. Albiez, M.; König, A.; Potthast, T. Bildung für Nachhaltige Entwicklung in Reallaboren. Die bildungsbezogenen Angebote des „Energielabors Tübingen“ in der Kinder-Uni Tübingen. TATuP 2016, 25, 41-45.

13. Albiez, M.; König, A.; Potthast, T. Transdisziplinarität und Bildung für Nachhaltige Entwicklung in der Lehre an der Universität Tübingen: Konzeptionelle Fragen mit Bezug auf Lehraktivitäten des “Energielabors Tübingen". In Nachhaltigkeit in der Lehre. Theorie und Praxis der Nachhaltigkeit; Leal Filho, W., Ed.; Springer Spektrum: Berlin/Heidelberg, Germany, 2018; pp. 189-206.

14. West, C. Wissen to Go-Transdisziplinär-transformative Lehre als „Reallabor im Kleinen”. In Transdisziplinär und Transformativ Forschen. Eine Methodensammlung; Defila, R., Di Giulio, A., Eds.; Springer VS: Wiesbaden, Germany, 2018; pp. 329-373.

15. Krütli, P.; Pohl, C.; Stauffacher, M. Sustainability learning labs in small island developing states: A case study of the Seychelles. GAIA 2018, 27, 46-51. [CrossRef]

16. Scholl, C.; de Kraker, J.; Hoeflehner, T.; Wlasak, P.; Drage, T.; Eriksen, M.A. Transitioning Urban Experiments: Reflections on Doing Action Research with Urban Labs. GAIA 2018, 27, 78-84. [CrossRef]

17. Parodi, O.; Waitz, C.; Bachinger, M.; Kuhn, R.; Meyer-Soylu, S.; Alcantara, S.; Rhodius, R. Insights into and recommendations from three real-world laboratories: An experience-based comparison. GAIA 2018, 27, 52-59. [CrossRef]

18. Singer-Brodowski, M.; Beecroft, R.; Parodi, O. Learning in real-world laboratories: A systematic impulse for discussion. GAIA 2018, 27 (Suppl. 1), 23-27. [CrossRef]

19. Jonassen, D.; Land, S. (Eds.) Theoretical Foundations of Learning Environments; Routledge: New York, NY, USA, 2012.

20. Land, S.M.; Hannafin, M.J.; Oliver, K. Student-centered learning environments: Foundations, assumptions, design. In Theoretical Foundations of Learning Environments; Jonassen, D., Land, S., Eds.; Routledge: New York, NY, USA, 2012; pp. 3-26.

21. Overdevest, C.; Bleicher, A.; Gross, M. The experimental turn in environmental sociology: Pragmatism and new forms of governance. In Environmental Sociology; Gross, M., Heinrichs, H., Eds.; Springer: Dordrecht, The Netherland, 2010; pp. 279-294.

22. Deutscher Bundestag (19. Wahlperiode). Einrichtung von Regulatorischen Experimentierräumen Bzw. Reallaboren. Antwort der Bundesregierung auf die Kleine Anfrage der Abgeordneten Dr. Petra Sitte, Birke Bull-Bischoff, Anke Domscheit-Berg, Weiterer Abgeordneter und der Fraktion DIE LINKE; Drucksache 19/3836; Bundesanzeiger Verlag GmbH: Köln, Germany, 2018.

23. Funtowicz, S.O.; Ravetz, J.R. Science for the post-normal age. Futures 1993, 25, 739-755. [CrossRef]

24. Gibbons, M.; Limoges, C.; Nowotny, H.; Schwartzman, S.; Scott, P.; Trow, M. The New Production of Knowledge: The Dynamics of Science and Research in Contemporary Societies; Sage: London, UK, 1994. 
25. Böhme, G.; Van den Daele, W.; Krohn, W. Die Finalisierung der Wissenschaft. Zeitschrift für Soziologie 1973, 2, 128-144. [CrossRef]

26. Almirall, E. Living Labs and open innovation: Roles and applicability. Electron. J. Virtual Organ. Netw. 2008, 10, 21-26.

27. Voytenko, Y.; McCormick, K.; Evans, J.; Schliwa, G. Urban living labs for sustainability and low carbon cities in Europe: Towards a research agenda. J. Clean. Prod. 2016, 123, 45-54. [CrossRef]

28. Menny, M.; Voytenko Palgan, Y.; McCormick, K. Urban Living Labs and the Role of Users in Co-Creation. GAIA 2018, 27 (Suppl. 1), 68-77. [CrossRef]

29. Baccarne, B.; Mechant, P.; Schuurman, D.; Colpaert, P.; De Marez, L. Urban socio-technical innovations with and by citizens. Interdiscip. Stud. J. 2014, 3, 143-156.

30. Juujärvi, S.; Pesso, K. Actor Roles in an Urban Living Lab: What Can We Learn from Suurpelto, Finland? Technol. Innov. Manag. Rev. 2013, 3, 22-27. [CrossRef]

31. Schliwa, G. Exploring Living Labs through Transition Management-Challenges and Opportunities for Sustainable Urban Transitions. Master's Thesis, University Lund, Lund, Sweden, 2013.

32. Steen, K.; van Bueren, E. The defining characteristics of urban living labs. Technol. Innov. Manag. Rev. 2017, 7, 21-33. [CrossRef]

33. Evans, J.; Jones, R.; Karvonen, A.; Millard, L.; Wendler, J. Living labs and co-production: University campuses as platforms for sustainability science. Curr. Opin. Environ. Sustain. 2015, 16, 1-6. [CrossRef]

34. Bulkeley, H.; Coenen, L.; Frantzeskaki, N.; Hartmann, C.; Kronsell, A.; Mai, L.; Palgan, Y.V. Urban living labs: Governing urban sustainability transitions. Curr. Opin. Environ. Sustain. 2016, 22, 13-17. [CrossRef]

35. Nevens, F.; Frantzeskaki, N.; Gorissen, L.; Loorbach, D. Urban Transition Labs: Co-creating transformative action for sustainable cities. J. Clean. Prod. 2013, 50, 111-122. [CrossRef]

36. Kemp, R.; Loorbach, D.; Rotmans, J. Transition management as a model for managing processes of co-evolution towards sustainable development. Int. J. Sustain. Dev. World Ecol. 2007, 14, 78-91. [CrossRef]

37. Nevens, F.; Roorda, C. A climate of change: A transition approach for climate neutrality in the city of Ghent (Belgium). Sustain. Cities Soc. 2014, 10, 112-121. [CrossRef]

38. Hall, P. Policy paradigms, Social Learning and the State: The Case of Economic Policymaking. Comp. Politics 1993, 25, 275-296. [CrossRef]

39. Van den Bosch, S. Transition Experiments: Exploring Societal Changes towards Sustainability. Ph.D. Thesis, Erasmus University Rotterdam, Rotterdam, The Netherlands, 2010.

40. Rotmans, J.; Loorbach, D. Transition management: Reflexive governance of societal complexity through searching, learning and experimenting. In Managing the Transition to Renewable Energy: Theory and Practice from Local, Regional and Macro Perspectives; Van den Bergh, J., Bruinsma, F., Eds.; Edward Elgar: Cheltenham, UK, 2008; pp. 15-46.

41. Scozzi, B.; Bellantuono, N.; Pontrandolfo, P. Managing open innovation in urban labs. Group Decis. Negot. 2017, 26, 857-874. [CrossRef]

42. Westberg, L.; Polk, M. The role of learning in transdisciplinary research: Moving from a normative concept to an analytical tool through a practice-based approach. Sustain. Sci. 2016, 11, 385-397. [CrossRef]

43. Shove, E.; Pantzar, M.; Watson, M. The Dynamics of Social Practice: Everyday Life and How It Changes; Sage: London, UK, 2012.

44. Spaargaren, G.; Weenink, D.; Lamers, M. (Eds.) Practice Theory and Research: Exploring the Dynamics of Social Life; Routledge: New York, NY, USA, 2016.

45. Kuijer, S.C. Implications of Social Practice Theory for Sustainable Design. Ph.D. Thesis, University Delft, Delft, The Netherlands, 2014.

46. Higginson, S.; McKenna, E.; Hargreaves, T.; Chilvers, J.; Thomson, M. Diagramming social practice theory: An interdisciplinary experiment exploring practices as networks. Indoor Built Environ. 2015, 24, 950-969. [CrossRef]

47. Meier, P.S.; Warde, A.; Holmes, J. All drinking is not equal: How a social practice theory lens could enhance public health research on alcohol and other health behaviours. Addiction 2018, 113, 206-213. [CrossRef] [PubMed]

48. Wilhite, H. Insights from social practice and social learning theory for sustainable energy consumption. Flux 2014, 94, 24-30. [CrossRef] 
49. Hargreaves, T. Practice-ing behaviour change: Applying social practice theory to pro-environmental behaviour change. J. Consum. Cult. 2011, 11, 79-99. [CrossRef]

50. Seebacher, A.; Alcántara, S.; Quint, A. Akteure in Reallaboren-Reallabore als Akteure. In Transdisziplinär und Transformativ Forschen. Eine Methodensammlung; Defila, R., Di Giulio, A., Eds.; Springer VS: Wiesbaden, Germany, 2018; pp. 155-159.

51. Zins, S. Transdisziplinäre Forschung als Impuls für die Nachhaltige Stadtentwicklung. Master's Thesis, Albert-Ludwigs-Universität, Freiburg, Germany, 2018.

52. Withycombe Keeler, L.; Beaudoin, F.; Lerner, A.; John, B.; Beecroft, R.; Tamm, K.; Wiek, A.; Lang, D. Transferring Sustainability Solutions across Contexts through City-University Partnerships. Sustainability 2018, 10, 2966. [CrossRef]

53. Dusseldorp, M.; Beecroft, R. (Eds.) Technikfolgen Abschätzen Lehren; Springer VS: Wiesbaden, Germany, 2012.

54. Scholz, R.W.; Tietje, O. Embedded Case Study Methods: Integrating Quantitative and Qualitative Knowledge; Sage: London, UK, 2002.

55. Steiner, G.; Laws, D. How appropriate are two established concepts from higher education for solving complex real-world problems? A comparison of the Harvard and the ETH case study approach. Int. J. Sustain. High. Educ. 2006, 7, 322-340. [CrossRef]

56. Holmberg, J. Transformative learning and leadership for a sustainable future: Challenge Lab at Chalmers University of Technology. In Intergenerational Learning and Transformative Leadership for Sustainable Futures; Hollingshead, B.P., Corcoran, P.B., Eds.; Wageningen Academic Publishers: Wageningen, The Netherlands, 2014; pp. 68-78.

57. Larsson, J.; Holmberg, J. Learning while creating value for sustainability transitions: The case of Challenge Lab at Chalmers University of Technology. J. Clean. Prod. 2018, 172, 4411-4420. [CrossRef]

58. Scholz, R.W.; Steiner, G. The real type and ideal type of transdisciplinary processes: Part II-What constraints and obstacles do we meet in practice? Sustain. Sci. 2015, 10, 653-671. [CrossRef]

59. Jahn, T. Transdisziplinarität in der Forschungspraxis. In Transdisziplinäre Forschung. Integrative Forschungsprozesse Verstehen und Bewerten; Bergmann, M., Schramm, E., Eds.; Campus Verlag: Frankfurt, Germany; New York, NY, USA, 2008; pp. 21-37.

60. Waitz, C.; Quint, A.; Trenks, H.; Lezuo, D.; Jäkel, A.; Wäsche, H.; Parodi, O. Das Reallabor als Motor für nachhaltige Quartiersentwicklung-Erfahrungen aus dem Karlsruher Experimentierraum. Berichte. Geographie und Landeskunde 2018, 91, 67-80.

61. Meyer-Soylu, S.; Parodi, O.; Trenks, H.; Seebacher, A. Das Reallabor als Partizipationskontinuum. Erfahrungen aus dem Quartier Zukunft und Reallabor 131 in Karlsruhe. TATuP 2016, 25, 31-40.

62. Waitz, C.; Meyer-Soylu, S. Das ReparaturCafé als Transformationselement im urbanen Raum. TATuP 2016, 25, 22-28.

63. Trenks, H.; Waitz, C.; Meyer-Soylu, S.; Parodi, O. Mit einer Realexperimentreihe Impulse für soziale Innovationen setzen-Realexperimente initiieren, begleiten und beforschen. In Transdisziplinär und Transformativ Forschen. Eine Methodensammlung; Defila, R., Di Giulio, A., Eds.; Springer VS: Wiesbaden, Germany, 2018; pp. 233-268.

64. Piaget, J. The Origins of Intelligence in Children; Cook, M.T., Translator; W W Norton \& Co.: New York, NY, USA, 1952. [CrossRef]

65. Wagenschein, M. Verstehen Lehren: Genetisch, Sokratisch, Exemplarisch; Beltz: Weinheim, Germany, 1999.

66. Churton, A. Kant on Education. Translation of "Über Pädagogik"; D.C. Heath \& Co.: London, UK, 1899. Available online: https: / Files.libertyfund.org/files/356/0235_Bk.pdf (accessed on 16 October 2018).

(C) 2018 by the author. Licensee MDPI, Basel, Switzerland. This article is an open access article distributed under the terms and conditions of the Creative Commons Attribution (CC BY) license (http://creativecommons.org/licenses/by/4.0/). 